http://dx.doi.org/10.11646/phytotaxa.167.1.7

\title{
New data on Salix anatolica (Salicaceae) endemic to Turkey
}

\author{
SALIH TERZİĞLU ${ }^{*}$, BEDRİ SERDAR ${ }^{1}$, MUSTAFA KARAKÖSE ${ }^{1}$, KAMIL COŞKUNÇELEBİ ${ }^{2}$ \& MUTLU \\ GÜLTEPE2 \\ ${ }^{1}$ Karadeniz Technical University, Faculty of Forestry, Department of Forest Botany, 61080 Trabzon, Turkey \\ ${ }^{2}$ Karadeniz Technical University, Faculty of Science, Department of Biology, 61080 Trabzon, Turkey \\ "author for correspondence, e-mail: sterzi@ktu.edu.tr
}

\begin{abstract}
The endemic Anatolian willow, Salix anatolica (Salicaceae), was described based on solely female individuals in 2008. It was re-collected and the description was emended based on both male and female flower properties in the present study. Additionally, the pollen morphology, wood anatomical features and conservation status of S. anatolica are presented for the first time.
\end{abstract}

Key words: Anatolia, Salix, pollen, willow, wood anatomy

\section{Introduction}

The genus Salix Linnaeus (1753: 1015) comprises deciduous and dioecious trees or shrubs. There are about 450 species of Salix mainly distributed in Asia, Europe and North America (Argus 1997, 2010) but there is still disagreement among authors regarding the number of species (Fang et al. 1999, Skvortsov 1999, Ohashi 2001, Heywood et al. 2007, Mabberly 2008). The members of the genus are native or planted mostly in wetlands, marshes, river banks, and along the sides of streams.

Including introduced ones, 27 Salix taxa are native to Turkey and four of them [Salix rizeensis Güner \& Zielinski (1993: 2), S. trabzonica Skvortsov (1971: 120), S. purpurea Linnaeus (1753: 1017) subsp. leucodermis Yaltırık (1989: 97) and S. anatolica Zielinski \& Tomaszewski (2008: 386)] are endemic (Güner et al. 2012). Willows are an important group of plants because of their ecological, economical and medicinal properties (Skvortsov 1999). They also have many traditional uses because of their role in ethnobotanical practices, such as basketry production and handcrafting (Arıhan \& Güvenç 2011).

Because of the phenetic plasticity and easy hybridisation in the wild the accurate identification and classification of willows is difficult. Additionally, Salix taxa often have different time of development for flowers and leaves so it is not always possible to observe all of the relevant characters on a single plant or specimen. Moreover, sometimes morphological characters are not sufficient to discriminate related species of Salix. Therefore, in addition to morphological characters, additional data, taken from palynological and anatomical studies provides valuable information for the systematics of Salix (Arrhan \& Güvenç 2011).

The purpose of the present study is to provide additional data on characters of male flowers of Salix anatolica, verify the sectional placement of the species according to female flowers, provide information about pollen grains and wood anatomy, and reassess the threat category of Salix anatolica.

\section{Material and methods}

Samples used for morphological, palynological and wood anatomical studies were collected from Southern Anatolia, Turkey (C5 Adana, Pozant1) in the years of 2011 and 2012. Some samples including male and female flowers were dried according to standard herbarium techniques and deposited in the herbarium of the Faculty of Forestry (KATO) at Karadeniz Technical University as Karaköse s.n. (KATO 8796, 8798, 8799). In the present study, the emended 


\section{Conservation status}

Salix anatolica, endemic to the East Mediterranean of Turkey, is known from three close localities along the Anatolian diagonal (Fig. 5). Currently it is under the detrimental effects of illegal cutting, road construction and forestry practice such as clear cutting. Therefore its threat category has been assessed as vulnerable (VU) based on the red list criteria of IUCN (2001).

\section{Additional Specimens Examined}

Salix anatolica:-TURKEY. Adana City: Pozant1-Çetinlik Region, stream valley within Lebanon Cedar-Black pine mixed forest, 1540 m, 09 May 2012, Karaköse s.n. (KATO 8799); same locality, 09 May 2012, Karaköse s.n. (KATO 8798), same locality, 10 May 2011, Karaköse s.n. (KATO 8796).

Salix pedicellata:-TURKEY. Trabzon City: Of-Uzungöl region, open area within forest, 1550 m, 20 August 1996 , Terzioğlu s.n. (KATO 11916).

Salix pseudomedemii:-TURKEY. Ardahan City: Posof-Çatalsular region, stream valley, 1820 m, 17 May 2001 , Serdar s.n. (KATO 15872).

\section{Acknowledgements}

The authors want to express their special thanks to Forest Engineers Bekir Demir and Musa Bozkurt for their logistic help supplying plant materials of S. anatolica and to Dr. Emin Zeki Başkent for his critically reading the manuscript.

\section{References}

Andersson, N.J. (1851) Ost-Indiens hittilis kända pilarter. Kongliga Vetenskaps-Akademiens Handlingar 1850: 463-502.

Argus, G.W. (1997) Infrageneric classification of Salix (Salicaceae) in the New World. Systematic Botany Monographs 52, $121 \mathrm{pp}$. http://dx.doi.org/10.2307/25096638

Argus, G.W. (2010) Salix L. In: Flora of North America Editorial Committee (eds.) Flora of North America North of Mexico 7. Oxford University Press, New York and Oxford, pp. 4-157.

Arıhan, O. \& Güvenç, A. (2011) Studies on the anatomical structure of stems of willow (Salix L.) species (Salicaceae) growing in Ankara province, Turkey. Turkish Journal of Botany 35: 535-551.

Babayi, F., Pakravan, M., Maassoumi, A.A. \& Tavasoli, A. (2012) Palynological study of Salix L. (Salicaceae) in Iran. Iranian Journal of Botany 18: 119-126.

Bieberstein, F.A.M. von (1819) Flora Taurico-Caucasica 3. Supplementum. Typis Academicis, Charkoviae, 654 pp.

Boissier, P.E. (1853) Diagnoses Plantarum Orientalium Novarum series 1, 1(7). B. Herrmann, Lipsia [Leipzig], pp. 1-130.

Çelemli, Ö.G. (2012) Pollen morphology of some Salix L. (Salicaceae) taxa used by honey bees as a source of pollen and nectar. Mellifera 12: $30-36$.

Desfontaines, R.L. (1799) Flora Atlantica 2. L.G. Desgranges, Paris, 458 pp.

Dumortier, B.C. (1862) Monographie des saules de la flore Belge. Bulletin de la Société Royale de Botanique de Belgique 1: 130-147.

Fahn, A., Werker, E. \& Baas, P. (1986) Wood anatomy and identification of trees and shrubs from Israel and adjacent regions. The Israel Academy of Sciences and Humanities, Jeruselam, $221 \mathrm{pp.}$

http://dx.doi.org/10.2307/1221471

Fang, Z., Zhao, S. \& Skvortsov, A.K. (1999) Salicaceae In: Wu, Z. \& Raven, P.H. (eds.) Flora of China 4. Science Press, Beijing and Missouri Botanical Garden Press, St. Louis, pp. 139-274.

Gmelin, S.G. (1774) Reise durch Russland 3. Kayserliche Akademie der Wissenschaften, St. Petersburg, 508 pp.

Güner, A., Aslan, S., Ekim, T., Vural, M. \& Babaç, M.T. (2012) Türkiye Bitkileri Listesi (Damarlı Bitkiler). NGBB ve Flora Araştırmaları Derneği Yayını, İstanbul, 1290 pp.

Güner, A. \& Zielinski, J. (1993) Salix rizeensis (Salicaceae): a new willow from NE Turkey. Karaca Arboretum Magazine 1: 1-5.

Heywood, V.H., Brummitt, R.K., Culham, A. \& Seberg, O. (2007) Flowering plant families of the world. Firefly Books Ltd., Ontario, 424 pp.

IAWA Committee (1989) IAWA list of microscopic features for hardwood identification. IAWA Bulletin 10: 221-332.

IUCN (2001) IUCN Red List Categories: Version 3.1. International Union for Conservation of Nature and Natural Resources, Gland and 
Cambridge, $70 \mathrm{pp}$.

Ives, E. (2001) A guide to wood microtomy: making quality microslides of wood sections. Ernie Ives, Suffolk, $124 \mathrm{pp}$.

Linnaeus, C. (1753) Species Plantarum. Laurentius Salvius, Stockholm, 1200 pp.

Maassoumi, A.A., Moeeni, F. \& Rahiminejad, M.R. (2008) New species and new records of the genus Salix (Salicaceae) from Iran. Iran Journal of Botany 14: 1-6.

Normand, D. (1972) Manuel D'Identification des Bois Commerciaux 1. Nogent Sur / Marne, Paris, 171 pp.

Ohashi, H. (2001) Salicaceae of Japan. Science Reports of Tohoku University 4th Series 40: 269-396.

Qureshi, R.A., Gilani, L., Gilani, S.J., Sultana, K.N. \& Ghufran, M.A. (2007) Palynological study of the genus Salix L. (Salicaceae) from Pakistan. Pakistan Journal of Botany 39: 2257-2263.

Punt, W., Hoen, P.P., Blackmore, S., Nilsson, S. \& Le Thomas, A. (2007) Glossary of pollen and spore terminology. Review of Palaeobotany and Palynology 143: 1-81.

http://dx.doi.org/10.1016/j.revpalbo.2006.06.008

Schweingruber, F.H. \& Baas, P. (1990) Anatomy of European woods: An atlas for the identification of European trees, shrubs and dwarf shrubs. Verlag Paul Haupt, Bern, 800 pp.

Serdar, B. (2003) Türkiye'de Doğal Olarak Yetişen Salicaceae Familyası Taksonlarının Ekolojik Odun Anatomisi. PhD Thesis, Karadeniz Technical University, Trabzon, 154 pp. [in Turkish].

Seringe, N.C. (1815) Essai d’une monographie des Saules de la Suisse. Chez la Société typographique, Berne, 110 pp.

Skvortsov, A.K. (1971) Salix L. In: Vasilchenko I. T. (ed.) Novitates systematicae plantarum vascularium 8. Amerind Publishing, New Delhi, $342 \mathrm{p}$.

Skvortsov, A.K. (1999) Willows of Russia and adjacent countries: taxonomical and geographical revision. University of Joensuu, Joensuu, $307 \mathrm{pp}$.

Skvortsov, A.K. \& Edmondson, J.D. (1982) Salix L. In: Davis P.H. (ed.) Flora of Turkey and the East Aegean Islands 7. Edinburgh University Press, Edinburgh, pp. 694-716.

Terzioğlu, S., Coşkunçelebi, K. \& Serdar, B. (2007) Contribution to the description of an endemic Turkish Salix species. Plant Biosystems 141: 82-85. http://dx.doi.org/10.1080/11263500601154055

Wodehouse, R.P. (1935) Pollen grains: Their structure, identification, and significance in science and medicine. McGraw-Hill Book Company Inc, New York, 574 pp.

Wolf, E.L. (1909) Salices rossicae novae. Trudy Imperatorskago S. Peterburgskago Botaniceskago Sada 28: 395-406.

Yaltırık, F. (1988) A new willow taxon for the flora of Turkey: Salix purpurea L. subsp. leucodermis Yalt. subsp. nova. İstanbul Üniversitesi Orman Fakültesi Dergisi ser. A 38: 92-98.

Zielinsky, J. \& Tomaszewski, D. (2008) Salix anatolica (Salicaceae) a new species from Turkey. Annales Botanici Fennici 45: 386-388 http://dx.doi.org/10.5735/085.045.0506 